DE DE GRUYTER

OPEN

DOI: 10.1515/aa-2015-0006

\title{
Decoding Samuel Beckett's language in Imagination Dead Imagine
}

\author{
Mária Kiššová \& L’ubomír Ščerbák
}

Mária Kiššová currently lectures on Children's literature, British literature, Romanticism and Cultural studies at the Department of English and American Studies at the University of Constantine the Philosopher in Nitra, Slovakia. Her publications include monographs Cultural Encounters in Contemporary Literature (with S. Hevešiová, 2008), Multicultural Awareness - Reading Ethnic Writing (with S. Hevešiová and A. Smiešková, 2008) and Literature and Culture (A. Pokrivčák, et al., 2010) and her reviews and interviews have also been published in the literary journal Ars Aeterna. Her field of interests covers a wide spectrum of interdisciplinary research including literature, art, cultural studies, philosophy, and religion.

Lubomír Ščerbák studied English language and literature at the Department of English and American Studies at the University of Constantine the Philosopher in Nitra, Slovakia. His interests include contemporary literature in English, philosophy and literature and interdisciplinary studies.

\begin{abstract}
The study focuses on the short prose text Imagination Dead Imagine (1965) by the Irish writer Samuel Beckett (1906-1989). It argues that while at first sight Beckett's text appears to be a chaotic verbal blend with no coherence, a close reading discloses an actual underlying pattern (mandala) which gives the text a structure and enables the reader to "understand" it. The authors of the paper claim that mandala, as the structural pattern of the text, represents an attempt to find a resolution of the existential and universal conflict within man. On one hand, there is spiritual alienation (exemplified here by the dissolution of the language) and, on the other hand, one's desire to be integrated with unity and return to the centre.
\end{abstract}

\section{Introduction: "Who knows what the ostrich sees in the sand?"}

While biologists tell us that ostriches do not bury their heads in the sand, the popular meaning of the saying refers to a situation when one is unable to confront or acknowledge a problem. Such behaviour is usually interpreted as cowardly and weak, yet the above question alters the perspective and one suddenly sees the ostrich's "situation" anew. The question shifts the focus from judgment about the ostrich-coward towards sympathy with another being whose behaviour we can never fully understand nor are we qualified to judge. ${ }^{\mathrm{i}}$ Imagination Dead Imagine (1965), published almost twenty years after his novel Murphy $(1938)^{\text {ii }}$ opens up - similarly to Beckett's other works - the existential problems of human existence. ${ }^{\text {iii }}$ The peculiarities of Beckett's poetics include the tone, subject matters and imagery (sad, dark, pessimistic, and mysterious) as well as the lack of logic, coherence, structure etc. 


\section{Language as a struggle for meaning}

Beckett's short text Imagination Dead Imagine comprises only 1,101 words; it has no punctuation, and what probably strikes many readers when they see the text for the first time is the number of seemingly inconsistent words, denoting concepts hard to decode, the whole text being resistant to plunge into any 'message'. The interconnections between words seem accidental, with no coherence, hence chaotic. ${ }^{\text {iv }}$ Another important feature of the text is the absence of characters and dialogues; there is only the so-called "vocal silence", which consists of the writer's words, and individual images.

Repeated readings, however, suggest the title $\mathrm{e}^{\mathrm{v}}$ to be the first major clue for interpretation. Using their imaginations, people generally create in their minds concepts related to a place or state evoking desirable emotions. Here, however, the imagination breaks down, vanishes, disappears, "dies", negating thus the human creative potential. The faculty whose nature is to create fails to do so. ${ }^{\mathrm{vi}}$

Focusing on the text sentence by sentence, one observes that the dimensions of time and space are absent, which - if one does not want to consider Imagination Dead Imagine a nonsensical combination of words - implies that the text either requires some special way of reading or the text's "purpose" per se is not to be "understood", i.e. to be made meaningful.

The continual change, inherent to nature and history (i.e. the "real"/"referential" world), occurs in temporal and spatial circumstances. If there is no time and space, there can be no change in motion, no evolution and no history. All that remains is "the being" and there is nothing that can "disturb" this state. Pure existence, without change, is eternally static. Beckett's text, as it can be derived from the suppression of space-time-existence, reveals change as undesirable and therefore to be avoided. ${ }^{\text {vi }}$ With his break from space-time, Beckett creates a fictional "inner" world that simply is, the perception associated with the meditation, concentration on the inner space that is static, which only exists. ${ }^{\text {vii }}$

The two minds, or better said, the two states of mind, important to distinguish in the process of meditation are known in Eastern spirituality as well as in Western traditional teaching and - in modern discourse - in psychotherapy, as Crabtree and Crabtree claim: "The inner mind is the font of all creativity and genius. It is the author of artistic productions, the inventor of original ideas, and the source of spontaneous solutions to problems. When it comes to creativity, the outer mind is subordinate to the inner." ${ }^{\text {"ix }}$ It means that the outer mind is "connected" to the palpable world and in a principle inferior to the inner mind which accepts all the stimuli that came as if from nowhere and is related to that which transgresses the personal. Crabtree and Crabtree further emphasize that "the inner mind's world is very real. Inner-mind realities have a quality of presence and vividness that is every bit as insistent as that of the physical objects and people of the outer world. In fact, the inner mind's reality often seems more real than that of the outer mind" (Crabtree, A. - Crabtree, E.). From the perspective of the distinction between the outer and the inner mind, Imagination Dead Imagine can be read as an expression of the inner world, as an attempt to get to the realm of "the unknowable" where, naturally, the dimensions of space and time do not exist. While such a task may seem impossible, the act of creating the text itself shows the author's yearning to share his "existential desire". 
In the following part, we show that although devoid of time and space, Beckett's work has a structure based on a specific archetypal pattern. This subsequently influences the text's interpretation, though it does not inevitably alter, nor contradict, the previously discussed views.

\section{Mandala as a unifying pattern}

Even though Imagination Dead Imagine seems at first sight meaningless, we would like to demonstrate that an underlying pattern/structure/code gives the text a centre and "makes" the reader's experience meaningful.

In order to see the unifying pattern of Imagination Dead Imagine clearly, we would like to quote the following part in which the pattern emerges:

Till all white in the whiteness the rotunda. No way in, go in, measure. Diameter three feet, three feet from ground to summit of the vault. Two diameters at right angles $A B C D$ divide the white ground into two semicircles $A C B$ BDA. Lying on the ground two white bodies, each in its semicircle" and "Still on the ground, bent in three, the head against the wall at $B$, the arse against the wall at $A$, the knees against the wall between $B$ and $C$, the feet against the wall between $C$ and $A$, that is to say inscribed in the semicircle $A C B$, merging in the white ground were it not for the long hair of strangely imperfect whiteness, the white body of a woman finally. Similarly inscribed in the other semicircle, against the wall his head at $A$, his arse at $B$, his knees between $A$ and $D$, his feet between $D$ and $B$, the partner. On their right sides therefore both and back to back head to arse (Beckett, 1965).

Evidently, Beckett depicts a formation and even gives the plan how to make it: at the beginning there are three points A, B and C described as "head", "arse", and "knees", connected subsequently through lines. After that, we may add point D into the drawing. When the points described as "arse", "head" and "knees" are connected, a square (the first part of the formation) appears which evokes the view from above. ${ }^{\mathrm{xi}}$ At the beginning of the text, Beckett mentions a rotunda. ${ }^{\text {xii }}$ If the elements drawn previously are seen from above, they represent the image of a circle, a rotunda from above. If the square and the circle are combined, the final pattern is a unity of a square imbedded in a circle, a mandala, with four points labelled as A, B, C, and D. The final image then consists of three elements which form the basic structure: the mandala ${ }^{x i i}$ itself and two formations inside it; one is similar to the letter " $Z$ " and the second one is its mirror reflection.

According to Snellgrove, the mandala represents the unity of cosmic reality, the unity of the material and the spiritual (Cairns, 1962). For this reason, creative production of mandalas may be viewed as a way to achieve this unity. ${ }^{\text {xiv }}$ Rudiger Dahlke, for instance, states that "[w]hen we occupy ourselves with a Mandala, its perfect structure has similar effects on our own structure" (Dahlke, 1992, p. 27). ${ }^{\mathrm{xv}}$ Or, to put it differently, "[c]ontemplating the mandala thus enables one to learn about one's situation, not because it presents a detailed map of the way things are, but because learning, as a clearly directed process of unlimited inquiry, is already transformation, already an opening up of new dimensions of both experience and behaviour through continually dissolving the horizons for explication set by what is known" (Hershock, 2010, p. 65). In its transcendental dimension, the mandala exists beyond time and space; yet, at the same time, it is a pattern of "this world". 
As Louise Child points out in a reference to Brauen, "although the mandala may be reproduced in two-dimensional images, what is represented is always understood to have a three-dimensional character" (Child, 2007, p. 7). Mandala, being simultaneously a condensed image of the universe and a symbol of the human body connects the macrocosmic and microcosmic realms of existence. First and foremost, however, the mandala is a regular geometric pattern which establishes a sacred space. Thus, the use of mandala in Imagination Dead Imagine can be seen as an attempt to transform and unite the spatial (geometric pattern) with the verbal, or, to put it differently, to verbalize the visual, the process through which one overcomes the limits of language.

The second element in the discussed picture is the pair of " $Z$ " formations. As a visual image, these Z-formations are similar to the foetal position of a child in its mother's womb, ${ }^{\text {xvi }}$ a posture which also has a religious significance. ${ }^{\text {xii }}$ Besides its relation to birth and new life per $s e$, this position is also connected with the notion of death-rebirth. ${ }^{\text {xiii }}$ Beckett's choice of position is further accentuated through his references to the words "kneel", "arse" and "head", all of which are direct signifiers of the corporeal and physical. The author's intention in using the mandala and an image of a human praying/lying in a foetal position can be interpreted as a desire to relate the actual (a visual image) and the transcendental. The voice of Imagination Dead Imagine is desperate to find peace and tranquillity; it manifests the agony of life, the will to finish the anguish. ${ }^{\text {xix }}$

Many of Beckett's characters are close to death, although, according to Badiou's observation, they never die (see Beckett's works Endgame, Happy Days, and Waiting for Godot.). ${ }^{\mathrm{xx}}$ At the same time, his characters see in death redemption, a way out of a life which seems unbearable, described by Navratilova (2013) as "the character's tragic lasting between life and death, which are not mutually exclusive; Beckett's characters live in a state which is a combination of these two and the only thing they long and hope for is the final arrival of 'real death' which never approaches quickly." Coming back to Imagination Dead Imagine, in the title itself one clearly recognizes a major tension of Beckett's discourse, since in the words of Christopher Ricks, “[o]ne's own death is unimaginable, since the imagination is itself a principle of life and an exercising of life" (1995: 45). ${ }^{\mathrm{xxi}}$

\section{Conclusion}

To conclude, we would like to return to the question mentioned in the introduction to our study. Beckett's literary/imaginative focus is always existential and while in the case of the ostrich it is the question that alters/disturbs the existential paradigm of the "usual"/"common" perspective, in Imagination Dead Imagine it is the pattern of the mandala which "makes the text meaningful" to us.

In our interpretation we suggested that the title of the discussed text may serve as a primary indication to its decoding. Besides that, there are also other possibilities of the title's interpretation which relate to and follow from all that had been already said about the text. The three initial letters of Imagination Dead Imagine (IDI) in their phonetic transcription resemble not only the word "idea" [ai, di: ai] but also the phrase "I thee I".

Reading any text, man's primary concern is the search for meaning, the idea/ideas which would make sense. The search for meaning is a universal search for pattern, order and logic that would turn chaos and disruption into a meaningful whole. Subsequently, we understand 
the phrase "I thee I" as an attempt to balance the dichotomy between the individual (personal) and the other. The text becomes meaningful only as a dialogue, if one presumes that there is a voice addressing him. It becomes meaningful only if confronted with the other. At the very end, however, there is always the return to the self, to "I".

In this way, Beckett's Imagination Dead Imagine is an imaginative expression of longing,

${ }^{i}$ The question about the ostrich can be read as Beckett's personal existential utterance which goes beyond created fictional reality and touches upon quintessential aspects of his life, philosophy and literary oeuvre. Although his biographer James Knowlson tries to alter the culturally stereotyped image of a reclusive and asocial person that many associate with Beckett and emphasizes the author's active social life (see Knowlson, 2004), Bram van der Velde states that "Beckett never wrote anything that he has not lived" (Velde, in Knowlson, 2004, p. xxi). Beckett's existential poetics makes him "the poet" of the postmodern age whose work blends the biographical and the fictional. While Beckett denied autobiographical echoes in his works (see for example Knowlson, p. xx-xxi), authoritative biographies by Deidre Bair, Andrew Gibson and even the one by James Knowlson give us a portrait of a loner most comfortable with silence and solitude (e.g. "Beckett's solitaire has not merely reconciled himself to his solitude. He has actively sought it out, having found no consolation in the outside world", Knowlson, p. 76). Knowlson further explains Beckett's palpable inclination to quietness and solipsism and one easily associates his inner struggles with the anxieties of characters in such texts as The Calmative, First Love and Imagination Dead Imagine: "[Beckett] was already clearly convinced that his physical problems were caused in part by his own attitude of superiority and an isolation from others that resulted from a morbid, obsessive immersion in self" (Knowlson, p. 180) and "[b]y externalizing some of the impulses of the psyche in his work - the feelings of frustration and repressed violence for example - he would find it easier to counter the self-absorption that had seemed morbid and destructive in his personal life" (Knowlson, p.181). Susan Mooney in her article about Andrew Gibson's biography remarks that Gibson also maintains the view that "Beckett's life experiences and observations are embedded in his works" (Mooney, 2012, p. 187).

ii It contains the question about the ostrich.

iii By existential we mean discourse on the meaning of life and its transcendental aspects; questions which define man as a being reflecting upon his own life. On the current difficulties of spiritual discourse see for instance Juhás, 2013.

${ }^{\text {iv }}$ See also Harper $(2012$, p. $151-162)$.

${ }^{\mathrm{v}}$ In the conclusion we also suggest other possibilities of its interpretation.

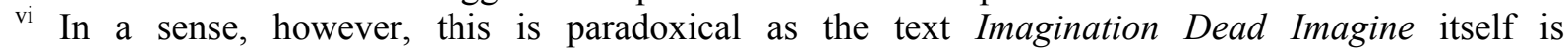
"created"/"imagined", approached and interpreted as a work of art, the work of imagination.

${ }^{v i i}$ This type of fictional world rightly provokes the question whether the text depicts "a reality" which is desired or whether it is simply a description of a state which does not have to be necessarily desirable. According to Knowlson, Beckett's philosophy was deeply influenced by Schopenhauer "who continued to influence his outlook, providing a clear justification for his view that suffering is the norm in human life, that will represents an unwelcome intrusion and that real consciousness lies beyond human understanding" (p. 268, italics by the authors of the paper).

viii Cf. Daniel Albright's reference to "a non-mimetic art" (in Ricks, 1995, p. 54).

${ }^{\text {ix }}$ See http://www.joannecrabtree.com/psychotherapyarts/innerMind/innerMind.htm.

${ }^{x}$ This "sacredness" of the creation of the text is what Beckett shares with John McGahern for whom writing - as suggested by Lýdia Čechová in her study of the author's works - is "a mysterious literary rite through which [the author] bridges the physical world with the infinite" $(2012$, p. 74 , translated by M.K.).

${ }^{\mathrm{xi}}$ All that can be seen so far is a square and a pair of lines similar to the foetal position of a child that will be discussed later.

${ }^{x i i}$ Rotunda also implies the transcendental discourse of Beckett's text. Coleston Brown mentions that the structure of a martyria, a type of early Christian church, "replicated the structure of the cosmos. The upper dome, representing the starry heavens, [...] sat upon a lower rotunda (representing the 
physical plane) [...]. At the centre of the rotunda was a shrine or edicule leading down to the actual cavern-tomb of Christ, representing the entrance to the UnderRealm" (2007, p. 18).

xiii See also Susan D. Brienza's analysis of Beckett's play Quad which she interprets through mandala symbolism: Samuel Beckett's New Worlds: Style in Metafiction, 1987; and Lidan Lin's study Samuel Beckett's Encounter with the East, 2010. On Beckett and Eastern spiritual discourse see also Kyle Gillette's Zen and the Art of Self-Negation in Samuel Beckett's Not I (2012).

xiv On the tension between man's existential incompleteness (separation, exile, duality etc.) and desire to achieve identification with the Absolute represented by the mandala, see also Čechová (2012, p. 20 29).

${ }^{\mathrm{xv}}$ The mandala should help to perceive separated elements as one unity. The elements have always been unified, yet, the limits of human perception, following the principle of dichotomy, compel us to believe that what is actually unified is perceived as separated. The mandala helps to overcome this fallacy.

${ }^{x v i}$ Knowlson's biography mentions Beckett's prenatal memories that appeared as part of his attempt to ease his depression: "I used to lie down on the couch and try to go back in my past. I think it probably did help. I think it helped me perhaps to control the panic. I certainly came up with some extraordinary memories of being in the womb. Intrauterine memories. I remember feeling trapped, of being imprisoned and unable to escape, of crying to be let out but no one could hear, no one was listening. I remember being in pain but being unable to do anything about it" (2004, p. 177).

${ }^{x v i i}$ For instance, according to Hain (2012), "[t]he bowing of head, the placement of knees, and the closing of eyes return us to the dark warmth of the womb. It is no coincidence that the posture of prayer and the fetal position bear great semblance. It is the womb that we are closest to God, furthest from the corruption of the world, and possess the least of what the flesh considers of value - our "brilliant" ideas, our "magnificent" plans, our "heroic" acts. It is also in the womb that we find ourselves in complete dependence. We receive all we need without knowing, without asking, without cost."

xviii In a description of North American burial grounds, Coleston Brown mentions that "[t]he bodies were sometimes placed in a flexed, fetal position as if being returned to the cosmic womb that they might be ready for rebirth" (2007, p. 17).

xix The motif of the inner struggle and an attempt to find tranquillity can be also found in Beckett's The Calmative and other texts.

${ }^{x x}$ See Gibson, 2010, p. 117. Cf. "Self-consciousness is one element in Beckett's vision of our vertigo, but only as another fruit of the ravening will to live" (Bloom, 1995, p. 463).

${ }^{\mathrm{xxi}}$ The dilemmas of biographical reading notwithstanding, Beckett's readers are openly confronted with the question: supposing that the author wanted to express his longing for harmony, what could cause his longing for it? For Beckett, there was something alluring in death. There is a rare disorder called Cotard's Syndrome, which also causes the delusion of one's death. The American psychiatrists Ruminjo and Menikulov define it in following way: "Cotard's syndrome is a relatively rare condition that was first described by Dr. Jules Cotard in 1882. Cotard's syndrome comprises any one of a series of delusions that range from a belief that one has lost organs, blood, or body parts to insisting that one has lost one's soul or is dead" (Ruminjo, Menikulov, 2008). For the context of Beckett and Cotard's syndrome, see Fifield, 2007/2008, p. 169-186.

\section{Works cited:}

Bair, D. 1990. Samuel Beckett: A Biography. London: Simon \& Schuster.

Beckett, S. Imagination Dead Imagine [Accessed 2013-28-01]. Available at http://www.samuelbeckett.net/ImaginationDeadImagine.html.

Bloom, H. 1995. The Western Canon. New York: Riverhead Books.

Brienza, Di, S. 1987. Samuel Beckett's New Worlds: Style in Metafiction. University of Oklahoma Press.

Brown, C. 2007. Magical Christianity: The Power of Symbols for Spiritual Renewal. Wheaton: Quest Books.

Bruns, G. L. 1969. The Storyteller and the Problem of Language in Samuel Beckett's Fiction. In Modern Language Quarterly, Vol. 30, Issue 2, p. 265 - 281. 
Cairns, G., E. 1962. The Philosophy and Psychology of the Oriental Mandala. University of Hawaii. [Accessed 2013-11-02]. Available at <ccbs.ntu.edu.tw/FULLTEXT/JR-PHIL/ew/25907.htm>. Child, L. 2007. Tantric Buddhism and Altered States of Consciousness. Ashgate Publishing Company. Crabtree, A., Crabtree, J.: Psychotherapy Arts. [Accessed 2013-29-01]. Available on the internet http://www.joannecrabtree.com/psychotherapyarts/innerMind/innerMind.html>.

Čechová, L. 2012. Medzi posvätnost'ou a každodennost'ou v tvorbe írskeho spisovatel'a Johna

McGaherna. In XLinguae: European Scientific Language Journal, Vol. 5, Issue 3, p. $74-85$. Čechová, M. 2012. K osnove praobrazov strádania v Kathásaritságare. In Rédey, Z. et al. Modely deficitných svetov. Nitra: UKF, p. 14 - 40.

Dahlke, R. 1992. Mandalas of the World: A Meditating \& Painting Guide. New York: Sterling. Fifield, P. 2007/2008. Beckett, Cotard's Syndrome and the Narrative Patient. In Journal of Beckett Studies, Vol. 17, Issue 1/2, p. 169-186.

Gibson, A. 2006. James Joyce. London: Reaktion Books.

Gibson, A. 2010. Samuel Beckett. London: Reaktion Books.

Gillette, K. 2012. Zen and the Art of Self-Negation in Samuel Beckett's Not I. In Comparative Drama, Vol. 46, Issue 3, p. 283-302.

Hain, H. Posture of Prayer. [Accessed 2013-11-02]. Available on the internet $<$ http://strawhutembassy.wordpress.com/2012/02/29/posture-of-prayer/>

Harper, M. P. 2012. Chaos as a Mode of Living in Samuel Beckett's The Unnamable. In Journal of Modern Literature, Vol. 35, Issue 4, p. 151 - 162.

Hayman, D. 2013. Joyce $\rightarrow /$ Beckett/Joyce. 2013. [Accessed 2013-28-01]. Available on the internet http://www.english.fsu.edu/jobs/num07/Num7Hayman.htm

Hershock, P. D. 2010. The Structure of Change in the Yijing. In Cheng, Chung-Ying - Ng, On-Cho (ed.): Philosophy of the Yi: Unity and Dialectics. Oxford: Wiley-Blackwell, p. 48-72.

Juhás, Vladimír (ed.). 2013. (Ne-)možnost' hovorit’ dnes o Bohu. Štúdie o (ne-)náboženskom jazyku. Prešov: Verbum - vydavatel'stvo KU.

Knowlson, J. R. 2004. Damned to Fame: The Life of Samuel Beckett. New York: Grove Press. Lin, L. 2010. Samuel Beckett's Encounter with the East. In English Studies, Vol. 91, Issue 6, p. 623642.

Mooney, S. 2012. Traces Historicized: Beckett Traced. In Journal of Modern Literature. Vol. 35, Issue 4, p. $187-191$.

Navratilova, E. 2013. The Absurdity of Samuel Beckett. [Accessed 2013-02-16]. Available at $<$ www.samuel-beckett.net/Absurdity.htm>

Ricks, C. 1995. Beckett's Dying Words: The Clarendon Lectures 1990. Oxford: Oxford University Press, 1995.

Ruminjo, A., Menikulov, B. 2008. A Case Report of Cotard's Syndrome. Matrix Medical

Communications. [Accessed 2013-28-01]. Available at

$<$ http://www.ncbi.nlm.nih.gov/pmc/articles/PMC2695744/> 
PhDr. Mária Kiššová, PhD.

Department of English and American Studies

Faculty of Arts

Constantine the Philosopher University in Nitra

Štefánikova 67

94974 Nitra, Slovakia

mkissova@ukf.sk

Mgr. L'ubomír Ščerbák

Independent researcher

lubomir.scerbak@azet.sk

\section{Acknowledgment}

This work was supported by a grant of the project VEGA: 1/0360/14: Osnovné tematické algoritmy $v$ slovesnom umení (s intersemiotickými a interdisciplinárnymi presahmi) and UGA I-14-201-00 Aspekty literárnej recepcie a interpretácie v praxi II. 